\title{
CONTOS DA MIÑA TERRA
}

\section{Takekazu Asaka}

Universidade de Tsudajuku

Toquio

doi:10.17075/rcsxxi.2014.058

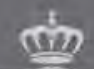

$=0=$ CONSELLO

+*t) DA CULTURA

GALEGA 

Álvarez, R. / A. Angueira / M. C. Rábade / D. Vilavedra (coords.) (2014): Rosalía de Castro no século XXI. Unha nova ollada, Santiago de Compostela, Consello da Cultura Galega. doi:10.17075/rcsxxi.2014. pp. 994-1037

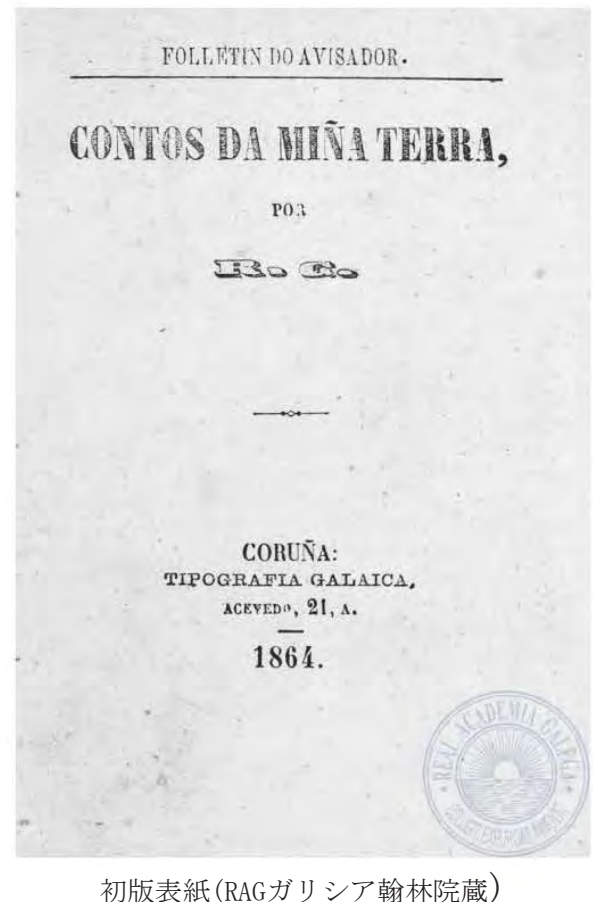


I.

Un dia d' inverno ó carr d' á tarde, dous amigos qu' eran amigos desd' á escola, e que contahan d'anos, ó maldito numero de tres veces doz, camiñaban á bon paso, un sobie un-ha mula branca, goria e de rerlondas ancas, y outro enriya d'os seus pes que non paiecian asanarse d as pasadas lixeiras que lles facia tar seu dono.

0 d' á pé, corria lanto com ó d' acabalo, que vendo ó sudor que lle corria o scu compañeiro po-la frente $y$ as puntas d' os cabelos, dixolle:

$$
\text { 一頁 (RAGガリシア翰林院蔵) }
$$


CONTOS DA MIÑA TERRA

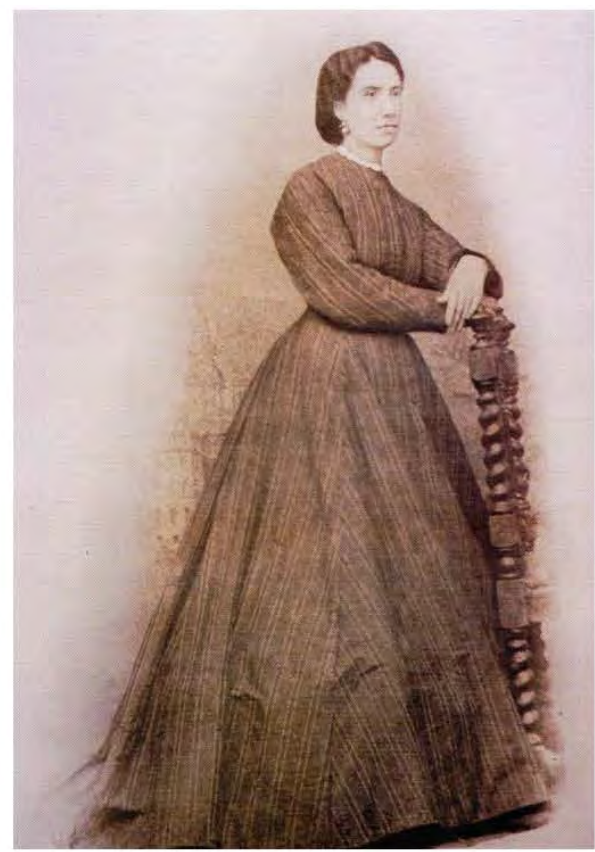

Rosalía Castro de Murguía (1860 ca.) 
A TABOA目次

Limiar Anxo Angueira
Prólogo M. Ríos Panisse
**********************
Contos da miña terra
Notas
わが故郷の昔話
おわりに
OCabo

O meu agradecemento a:

Real Academia Galega, Instituto da Lingua Galega

e dona Emilia Montero (a cuberta) 


\section{LIMIAR}

Anxo Angueira

Takekazu Asaka xa xuntara o seu nome ó de Rosalía de Castro ó traducir a obra emblemática da autora e unha referencia principal da literatura galega contemporánea: os Cantares gallegos. Volve agora Takiño, como familiarmente lle chamamos en Galicia, a construír unha nova ponte entre Galicia e mailo Xapón. Desta vez tócalle ao único conto que conservamos da serie «Contos da mińa terra» (1864). Trátase dunha proba máis das estratexias profundamente renovadoras con que Rosalía trata a fonte popular. O conto do que Rosalía parte, do que temos referencias de hai máis de dous milenios (Fedro e Pedronio), era desde a súa orixe un conto misóxino. O conxunto das alteracións efectuadas sobre a base do conto popular traballan nunha dirección non estritamente recreadora, senón rompedora: darlle un papel novo á muller no conto e pór de relevo unha lectura feminista do mesmo. Neste sentido, o espírito do pobo, o Volksgeist de Herder, fica redireccionado cara a posicións de pensamento crítico. Que Rosalía se revire contra os discursos reaccionarios da tradición literaria popular non é nada novo na autora. Xa en Cantares o fixera, coma no caso emblemático e similar tematicamente de «San Antonio bendito / dádeme un home / anque me mate, / anque me esfole».

Saúde, pois, para esta nova Rosalía en xaponés. Na horta da súa Casa-Museo da Matanza (Padrón) florecen neste tempo abondosas as camelias que viñeron de oriente nas máis diversas castes. Cando lle houbo que buscar unha imaxe ó proxecto de tradución de Rosalía ás máis diversas linguas chamado «Rosalía é mundial», atopamos como mellor emblema precisamente o da camelia. Pontes coma esta que agora o lector ten entre as mans son as camelias literarias que a humanidade precisa para mellor entenderse a si mesma e que Takekazu Asaka cultiva no seu particular xardín de traballo.

Presidente da Fundación Rosalía

Padrón, 22 de abril de 2014 


\title{
PRÓLOGO
}

\section{O Conto gallego de Rosalía de Castro}

\author{
M. Ríos Panisse
}

\section{Situación da prosa galega en 1860 (noticia para xaponeses)}

Rosalía de Castro (Santiago de Compostela, 24 de febreiro de 1837 - Padrón, 15 de xullo de 1885) é a autora máis importante da Literatura Galega. A súa obra publícase durante o século XIX, no período chamado Rexurdimento.

Durante a primeira metade do século XIX considerábase o galego como unha lingua ágrafa porque se descońecía a rica e interesante literatura medieval do século XIII.

Nesa época, os defensores dunha cultura específica para Galicia empezaron a escribir en lingua castelá durante os anos 1840-50; só despois comezaron a empregar o galego na poesía lírica e pseudo-folclórica. Foi, precisamente, Rosalía de Castro a autora do primeiro libro poético importante desta etapa: Cantares gallegos (1863), unha glosa, interesantísima e de gran valía artística, de diferentes cantares populares. $\mathrm{O}$ paso seguinte foi consolidar a poesía lírica, que tamén fixo Rosalía no seu libro Follas novas (1880). Finalmente, deberíase crear en lingua galega a poesía épica, labor que recaeu sobre Eduardo Pondal (1835-1917), que o conseguiu cunha obra titulada Queixumes dos pinos (1886).

A prosa en galego tińa que esperar. A lingua non se consideraba dabondo elaborada. De feito, son contadas as páxinas en prosa galega anteriores aos anos 1880, data a partir da que diversos autores (Marcial Valladares, Antonio de la Iglesia e outros) empezan a usala en recreacións de contos populares.

De aí que sexa tan interesante a aventura que se inicia co Conto gallego, primeiro texto narrativo en prosa literaria que se publica en lingua galega.

\section{Edicións do conto}

En 1864, baixo o título de Contos da miña terra, publicou Rosalía de Castro, por primeira vez, o seu único relato en prosa galega, cońecido, normalmente, 
como Conto gallego. Fíxoo, en forma de folletín, nun xornal corunés de tendencia liberal avanzada, chamado El Avisador, e asinouno coas iniciais R. C. Catro anos despois, foi novamente impreso en El Eco Ferrolano, outra publicación periódica que o deu tamén como folletín, esta vez xa baixo a autoría clara de Rosalía Castro de Murguía.

Quizais por aparecer as dúas veces como coleccionable (follas recortables dun xornal), debeu ser unha rareza só conservada por algún curioso, ou, talvez, por estar en prosa nunha época en que a lingua galega só se consideraba idónea para a poesía, os Contos da miña terra ficaron descońecidos para os estudosos da autora, ata que en 1923 apareceu, transcrito dun manuscrito inédito, baixo o título de Conto Gallego en Buenos Aires, no tomo 26 do Almanaque Gallego, fundado e dirixido por Manuel Castro López. A partir de entón, empezou a figurar na bibliografía rosaliana, que considerou a de 1923 a primeira edición. Como Conto Gallego (sempre baseado no texto do manuscrito) volveu publicarse en 1946, en Cuadernos de Estudios Gallegos; en 1970, foi reproducido baixo o título de Contos do pobo nun dos tomos da colección «O Moucho» da Editorial Castrelos. En 1995, deixa de ser considerado "póstumo" ao aparecer o exemplar de ElAvisador e, en 2012, confírmase a autoría de Rosalía de Castro coa aparición do exemplar de El Eco Ferrolano, nos dous casos co título orixinal de Contos da miña terra.

\section{Intención do conto}

Parece probable que Rosalía de Castro, quizais influenciada polo éxito das glosas de Cantares gallegos, e estimulada polo exemplo da escritora Fernán Caballero (que recolleu e publicou reelaborados uns anos antes unha colección de contos andaluces), se sentise tentada de iniciar en prosa unha serie de contos tamén de orixe popular. Por iso a colección recibiría o título de Contos da miña terra doadamente asociable cos Cantares gallegos. En favor desta suposición está o feito de que o título faga referencia á inclusión de varios contos, aínda que só aparecese o cońecido como Conto gallego. Tamén apoia esta teoría o feito de que o número I encabece a publicación, dando a entender que haberá un II, un III, un IV, etc.

\section{Orixe popular}

O Conto galego pertence ó grupo máis numeroso dos contos populares, o dos contos humorísticos. Rosalía recrea un relato sobre a versatilidade amorosa femi- 
nina, vista a través da viúva inconsolable. Trátase dun tema universal; no catálogo Aarne-Thompson é o tipo 1510 (The Matron of Ephesus, chamado así porque a protagonista da primeira versión que se coñece, narrada por Petronio no Satyricon, é unha matrona [viúva] de Éfeso).

Camiño Noia, no seu Catálogo tipolóxico do conto galego de tradición oral (Universidade de Vigo, 2010), dá conta de seis versións orais galegas, recollidas por Lois Carré (en Monforte, Lugo), Fanny López Valledor (en Ibias, Asturias), Camiño Noia (en Outes, A Coruña), Aquilino Poncelas (en Sigüeya-Benuza, León), M. ${ }^{a}$ del Carmen García García (en Castropol, Asturias) e C. Ríos Panisse (no Vicedo, Lugo). Tamén se dá noticia das versións literarias que coñeceu.

O Conto gallego de Rosalía, aínda que é unha reelaboración literaria, procura manter a estrutura do relato oral, tanto na conservación de clixés (formulas iniciais, finais, refráns e ditos populares) como na redución da parte narrativa en favor da parte dialogada, que fai semellar moitas veces que nos atopamos máis diante dunha peza teatral ca narrativa. Tamén procura enriquecer a tensión do relato, dando importancia á anécdota central con ideas e situacións que axuden o lector a interesarse polo relato, eliminando ambigüidades, incrementando a coherencia e salientando o humor.

O relato progresa en forma lineal en tres partes:

a) Introdución, na que se presenta aos personaxes e se realiza a aposta da mula.

b) Nó, onde o personaxe, que dubida da fidelidade da muller, consegue conquistala.

c) Desenlace, no que a simulada pena feminina pola perda do marido aparece contrastada coa auténtica anguria do perdedor da mula.

\section{Conclusión}

Rosalía de Castro, a quen debemos a demostración da valía lírica da lingua galega, iniciou con este conto o uso literario en prosa. Mágoa que o seu proxecto quedase reducido a un só conto e que tivésemos que agardar uns vinte anos para empezar a ver de novo recreados contos populares en forma culta, primeiro paso para preparar a aparición da novela e do ensaio, que só se dá en galego a partir do século XX. 


\section{Bibliografía}

Bouza Brey, Fermín (1946). «Escritos no coleccionados de Rosalía Castro (VI)», Cuadernos de Estudios Gallegos, tomo II, pp. 279-294, Santiago de Compostela.

Castro, Rosalía de (1970). Contos do pobo. Edicións Castrelos. Vigo.

- (1977). Obra completa, volume II. Aguilar, Madrid. Recompilación e introdución de Victoriano García Martí. Nova edición aumentada por Arturo del Hoyo. (Publica o conto).

Castro López, Manuel de (1923). «Conto gallego por Rosalía Castro de Murguía» en Almanaque Gallego, t. 26, pp. 95-104, Buenos Aires.

Noia Campos, M. ${ }^{a}$ Camiño (2010). Catálogo tipolóxico do conto galego de tradición oral, Secretariado de Publicacións, Universidade de Vigo. (Tipo 1510).

Ríos Panisse, M. ${ }^{a}$ C. (1994). «Contos da miña terra (1864), primeira edición do Conto gallego, atribuído a Rosalía de Castro», Grial 126, t. XXXIII, pp. 157-180, Galaxia, Vigo. (Reedita o conto).

- (1999) "A orixe popular de Contos da miña terra (Conto gallego), obra atribuída a Rosalía de Castro», en Homenaxe ao profesor Camilo Flores, edición coordinada por M. a Teresa García-Sabell Tormo, Manuel Míguez Ben, Emilio Montero Cartelle, Manuel Vázquez Buján e José M. ${ }^{a}$ Viña Liste, t. II, pp. 606-625, Publicacións da Universidade de Santiago, Santiago de Compostela. (Publica os tres contos).

Torres Regueiro, Xesús (2012). «O 'Conto galego’ de Rosalía. Unha edición ferrolá asinada pola autora en 1868», Grial 195, t. L, pp. 118-123, Galaxia. Vigo. 
Takekazu Asaka 
CONTOS DA MIŃA TERRA 
Un dia d'inverno ó caer d'á tarde, dous amigos qu'eran amigos desd'á escola, e que contaban d'anos, ó maldito número de tres veces dez, camiñaban á bon paso, un sobre un-ha mula branca, gorda e de redondas ancas, y outro enriva d'os seus pes que non parecian asañarse d'as pasadas lixeiras que lles facia dar seu dono.

O d'á pé, corria tanto com'ó d'acabalo, que vendo ó sudor que lle corria ô seu compañeiro po-la frente y as puntas d'os cabelos, dixolle:

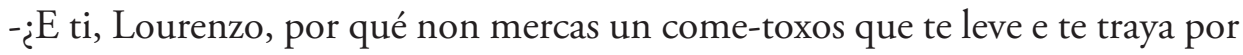
estes camiños de Dios? Qu' esto d' andar leguas á pé por montes e areales é bó pr'os câs.

¡¡Come-toxos! Anda, e qu'os monten aqueles prá quen se fixeron que n’é Lourenzo. Cabalo grande, ande ou non ande, e xa que grande n'o podo ter, sin él me quedo e sirvome d'os meus pés que nin comen, nin beben, nin lle fan menester arreos.

-Verdade'é qu'ó teu modo de camiñar é mais barato que ningun, ¡negro de min! qu'hora teño que pagar ó portasgo solo por que vou en besta, e non coma ti, nestes pés que Dios me dou. Pro... asi com'asi, gusto da andar as xornadas en pernas alleas prá c'as d'un non cansen, e x'ó dixen; debias mercar un farroupeiro pr'o teu descanso. Mais ti fas com'ó outro, oxe ó gano, oxe ó como, que mañan Dios dirá. Nin tes arrello nin cousa qu'ó valla; gùstanch'os virvirichos y as virviricheiras, ó viño do Riveiro e as ostras d'o Carril. ¡Lourenzo! debias casarte qu'ó fin ó tempo vay andando, os anos corren, e un probe d'un home faise vello e cróbese de pelos brancos antes de que poida ter manta na cama, e aforrar prá un-ha occasion; e esto, Lourenzo, non se fay sin muller que teńa man da casa e garde ó diñeiro qu’un gana.

-Boy solto, ben se lambe.

¡O vento! Esas sonche faladurias. ¿ $\mathrm{O}$ derradeiro, prá qu’os homes naceron, si non he pr'axuntarse c'as mulleres, fillo da tua nay? (Lourenzo tuse). Seica te costi- 
paches co resio da serán, malo de ti. (Lourenzo volve á tusir). Léveme Dios si n’é certo, e tanto non tusiras si ora viñeras á carrancha perna, enriva d'un farroupeiro.

¡¡Costipad'eu! No estiven na miña vida, e penso qu'ora tampouco. Pro... sempre que se me fala de casar, dam'un-ha tos que... jhem!... jhem!... e seica esto, n'e boa sinal. ¿Non ch'ó parece, Xan?

-O que me pares é qu'eres rabudo com'as uvas de cacho, e eso venche xa da nacenza, que non po-lo ben que t'estimo deixo de conocer qu'eres atravesado com'os cangrexos. Nin podo adiviñare por que falas mal d'as mulleres, que tan ben te queren, e que t'arrolan nas fiadas e nas festas, com'á fillo de rey, e sabendo que tua nay foy muller, e que si tua nay non fora ti non vińeras ó mundo coma cad'un de tantos.

-Nin moito se perder'anque nunc'acá chegara. Que mellor que sudando polos camińos prá ganar ó pan da boca, e mellor que rechinar nas festas e non-nas festas con meniñas que caras se venden sin valer un chavo, enganand'os homes, estaria aló na mente de Dios.

-¡Diancre d'home! que mesm'as veces penso s'eres d'aqueles que saùdan o crego solo por que non digan. E pois ti és dono de decir canto queiras, pró eu tamen che digo que me fay falla un acheguiño, e que me vou casare antes d'á festa, asi Dios me dé saúde.

-E premita el Señor que non sudes moito, Xan, anqu'ora é inverno, qu'entonces si qu’inda tusirás ${ }^{1}$ mais qu'eu, cando de casar me falan. E adivirtoche que teñas tino de non matar carneiros na festa, qu'é mal encomezo pr'un casado, por aquelo d'os cornos retortos que se guindan ó pé da porta, e xa se sabe qu'un mal tira por outro. ¡Dio-no-libre!

- ¿E ti quês saber que xa me van parecendo contos de vella, todo eso que se fala de cornos, e da maldades d'as mulleres? Pois cando nesta nosa terra se da en decir qu'un can rabiou, sea certo ou non sea, corr'á bola e mátase ó can. Mais eu por min ch'aseguro que n'atopey nunca muller solteira que non se fixese muy rogada, 
nin casada qu'ó seu home comigo faltase; e paréseme qu'ainda non fago tan mal rapaz, anqu'ó decilo sea fachenda.

-E qu'eso vay no axeitarse, e ti seica n'acertache, Xan; c'ó demais, com'un home queira, non queda can tras palleiro.

Eu ch'ó digo, n'hay n'este mundo mais muller boa pro'os homes, qu'aquela qu'os paríu, y asi arrenega d'elas coma do demo, Xan, qu'á muller demo é, segun dí non sey que santo moy sabido; y ó demo, hastr-á cruz lle fay ôs cornos de lonxe.

-Volta c'os cornos.

-E ten sabido que si tanto che fay anomealos, é por que xa che dan sombra dend'o tellado d'á qu'á de ser tua muller.

- ¡Seica me queres aqueloutrare! Pouco á pouco, Lorenzo, que nin debes falar asi de quen non conoces, nin todalas mulleres han de ter ó ollo alegre, que de moitas eu sey por quen se poidera pońer, non unha, si non cen vidas.

-O dito, dito queda, que cando eu falo é con concencia; e repítoche que sendo muller, non quedo por ningun-ha, anque sea condesa ou de sangre nobre, como solen decir, qu'un-has e outras foron feitas d'un-ha mesma masa e coxean do mesmo pé. Dios che mas libre do meu lar, qu'ora no lar alleo ainda n'as cuspo.

-¡Ah! ladron d'a honra allea, lévech'o deño s'eu quixera que cuspiñases na do meu, qu'o pensamento de que quixais terey que manter muller prá un rabudo coma ti, faime pôr os cabelos dreitos, e o intendimento pensatible. Pro... falemos craros. Lourenzo, coma bos compañeiros que somos. Ti es mas ${ }^{2}$ listo qu'eu, ben ó vexo, e por dond'andes sabes t'amañar qu'adimira, mentras qu'eu me qued'ó pé d'o lume, vendo com'o pote ferve e cantan os grillos. O conto vay no amaño... pro esto de qu'as has de votar todas nun-ha manada, sin deixar un-ha prá min, vállanme todo-los santos que me fay suare. ¡Vaya! dime qu'ainda viches mulleres boas, e que non todas lle saben poñer á un home honrad'os cornos na testa. 
-Todas, Xan... todas, e pr'os Xans, ainda mais; que mesmo parés qu'ó nom'as atenta.

-¡Condenicado de min, que seiqu'é certo! Pró meu pay e mińa nay casàronse, e yeu tamen me quero casare, que mesmo se me van os ollos cando vex'ó anoitecido un matrimonio que fala pasenińo sentado á porta da eira, mentras corren os meniños á luz d'o luar por embaixo d'as figueiras.

- $\mathrm{O}$ aire, o aire! e déixate de faladurias! paseniño, que paseniño tamen se dan veliscos e rabuñadas, e paseniño se fan as figas.

-En verdade, malo me vay parecend'o casoiro, pro moito me temo qu'a aficion no me faga prevaricare; mais sempre que me case, casareime cun-ha do meu tempo, cheiña de carnes, con xuicio e facendosa, que poida que neso n'axa tanto mal...

¿Qué me dís?

-Qu'es terco com'un-ha burra. Tí te-lo deño, Xan, y ora estache facend'as cóchegas c'o casoiro. Pró ten entendido que non hay volta si non que Dio-lo mande, que tratándose d'aquelo da fraqueza d'as mulleres, todas deitan coma cestas, e cân coma si non tivesen pês.

Asi falando Xan e Lourenzo, iban chegando á cerca d'un lugar; e como xa de lonxe empezasen á sentir berro e chorros, dempois de subirse á un alto, por saber o qu'aló pasaba, viron qu'era un enterro, e á un rapaz que viña po-lo camiño perguntáronlle po-lo morto, e respondeulles qu'era un home d'un-ha muller qu'inda moza quedaba viuda e sin fillos, que nunca tivera, e que tińa n'outra hardeiros.

Fois'o rapaz, e Lourenzo chegándose á Xan dixolle estonces:

-¿E ti quês, Xan, que che faga ver o que son as mulleres, qu’ora a ocasion é boa?

$-¡$ ¿E pois cómo? 
-Facendo qu'esa viuda, que non sey quen é, nin vin na miña vida, me dé nesta mesma noite palabra de casamento prá d'aqui á un mes.

-¿E ti estás cordo, Lourenzo?

-Mais que ti, Xan; ¿qués ou non qués?

-E pois ben, tolo. Vamos á apostare, e si ganas, perdo á miña mula branca qu'herdei de meu pay logo fará un ano, e qu'a estimo por isto, e por ser boa, com'as niñas d'os ollos. Curareime entonces do mal de casoiro: pró si ti perdes, tes que mercar un parroufeiro e non volver á falar mal das mulleres, miñas xoyas, qu’ainda as quero mais qu’á mia muliña branca.

-Apostado. Báixate, pois, da mula, e fay desd'ahora tod'o que ch'eu diga sin chiar, e hastra mañan po-la fresca, nin tí es Xan, nin eu Lourenzo, si non que ti es meu criado, y eu son teu amo. Agora ven tras min tendo conta da mula, qu' eu irei diante, e dí á todo amen.

Meu dito, meu feito.

Lourenzo tirou diante, e Xan votouse á pé, indo detrás, c’a mula po-las bridas que eran novas asi com'os demais arreos, e metian moita pantalla.

O mesmo tempo que eles iñan chegand'o Campo Santo, iña chegando tamen o enterro, rompendo a marcha o estandarte negro e algo furado d'a parroquia, o crego y as mulleres que facian o pranto, turrando polos pelos como si fosen cousa allea, berrando hasta enroucare, e agarrandos'a tomba de tal maneira que non deixaban andar ôs qu'a levaban.

-¡Ay, Anton! ¡Anton! desia un-ha poñéndose com’á Madanela, c’as mans encruzadas enriba d'a cabeza. Anton, meu amigo, que sempre me decias: -jAdios, Mariquiña! Cando m’atopabas no camiño. ¡Adios, Anton, que xa non te verey mais! 
Y outra inda arrastro detrás da caixa, e pegando en si, desia tamen:

- ¿En dónde estás, Anton, que xa non me falas? Anton, malpocadiño, que che fixeron as miñas mas uns calzós de lenzo cruo e nos puxeches, Anton; ¿quen ha de pór agora a tua chaqueta nova y os teus calzós, Anton?

Y a viuda, e un-has sobrińas da viuda, todas cubertas de bagoas, vestidas de loito, e os periquitos desfeitos de tanto turrar por eles, e os panos desatados, berraban ainda mais; sobre todo a viuda, que indo de cando en cando á meterse debaixo da mesma tomba, de dond'a tiñan quarricar por forza, decia:

-¡Ay meu tio! ¡A Ay meu tio, bonito com'un-ha prata, e roxińo com'un ouro, que cedo che vay comela terra as tuas carniñas de manteiga! ¡E ti vaste, meu tio! ¿Ti vaste? ¿E quén sera agora o meu acheguiño, e quén me dirá como me decias ti, meu ben:

-Come, Margadiriña, come prá engordare, qu’o que teu é meu, Margarida ${ }^{4}$, e si ti coxeas, tamen á min me parese qu'estou coxo? ¡Adios, meu tio, que xa nunca mais durmiremos xuntińos n’un leito! ¡Quén me dera ir contigo na tomba, Anton, meu tio, qu'ó fin contigo, miña xoińa, entérrase o meu corazon!

Asi a viudiña se desdichaba seguind'ó morto, cando de repente, meténdose Lourenzo antr'as mulleres cubertos os ollos c'un pano, e saloucando como si lle sahisse da yalma, escramou berrando ainda mais qu'as do pranto.

-¡Ay, meu tio! ¡Ay, meu tio, qu’ora vexo ir mortińo n’esa tomba! Nunca eu aqui viñera prá non t'atopar vivo, e n'é po-lo testamento que fixeches en favor meu, deixándome por hardeiro de canto tes, po-lo qu'eu tanto te choro, que sempre te quixen com'á pay, e esto de que me habias de chamar para despedirte de min e que tei de ver xa morto, pártem'as cordas do corazon. ¡Ay! meu tio! que mesmo me morro c'a pena.

Cando esto oiron toda-las do pranto, puñeron á redor de Lourenzo, que mesmo se desfacia á uńa de tanta dôr como parecia ter. 
${ }_{\imath}$ E logo ti cómo te chamas, meu fillo? lle preguntaron moy compadecidas d'ele.

-Eu chámome Andruco, e son sobriño do meu tio, que me deixou por hardeiro e me mandou chamare por un-ha carta prá se despedir de min antes de morrer; pró como tiven qu’andar moita terra, xa solo o podo ver na tomba. ¡Ay, meu tio!

- E ti d'ondés, moso?

-Eu son da terra do meu tio, volveu á desir Lourenzo, saloucando hastra cortárselle á fala.

$-\_$E teu tio d'ond'era?

-Meu tio era d'a miña terra.

E sin qu'o poideran quitar d'esto, Lourenzo, proseguindo co pranto, foise achegando á viudiña, qu'ainda pro $^{5}$ antr'as bagoas qu'a cubrian poido atisvare aquel moso garrido que tanto choraba po-lo seu tio. Dempois que se viron xuntos, logo lle dixo Lourenzo qu'era o hardeiro do difunto, y ela mirouno con moy bos ollos, e acabad'o enterro, dixolle que tiña qu'ir co ela á sua casa, que n'era xusto parase n'outra o sobriño d'ó seu home, e qu'asi chorarian xuntos a sua disgrasia.

-Disgrasia moita. ¡Ay, meu tio! dixo Lourenzo; pró... consoládevos que c’o qu'él me deixou conto facerlle decir moitas misas po-la yalma, prá qu'él descanse e poidamos ter nos tamen mayor consolo acá na terra, c’ó fin, ñ’a tia, Dios mándanos ter pacencia c'os traballos, e... que queiras que non queiras, coma dix'o youtro, a terriña cái enriba d'os corpiños mortos, e..., ¿qué hay que facer?... nós tamen temos qu'ir, qu'asi é o mundo.

Asi falando e chorando, tornaron camiño d'a casa d'á viuda, e Xan qu'iba detràs c'o á mula, e que n'un prencipio non entendera nin chisca do que queria facer Lourenzo, comenzou á enxergare, e pasoull'asi po-las carnes un-ha especie 
d'escallofrio, pensando en s'iria á perder a sua muliña branca. Anqu'á ver o dôr e as bagoas d'á viudińa, que non lle deixaban de correr á fio po-la cara afrixida, volveu á ter confiansa en Dios e nas mulleres á quen tan ben queria.

-E vos, ñ’a tia, ¿̇terés un sitiño prá meter esta mula y o meu criado, qu'un e outro de tanto camińare veńen cansados coma raposos?

-Tod'o terey prá vos, sobriño d'o meu tio, que mesmo con vervos pareceme c'o estou vendo, e sérveme de moito consolo.

-Dencho c’a viudiña, os consolos qu’atopa; marmurou Xan prá si metendo a mula no presebe. Pró de isto á casare, añadeu contento de si mesmo, ainda hay lamare ${ }^{6}$.

E c'o esta esperansa puxos'á comer con moitas ganas un bo anaco de lacon, qu'á viuda lle dou mollándoo c'un-ha cunca de viño d'o Riveiro qu'ardia n'un candil, e que ll'alegrou á pestana, mentras tia e sobriño estaban aló enriba no sobrado, falando d'harencia e do morto, c'os qu'os acompañaban.

D'esta maneira pasous'o dia, e chegou á noite, e quedaron soyos na casa a viuda, Lourenzo e Xan, que dês que viu cerrar as portas estuvo á axexa, c’o corason posto na mulińa branca, a yalma en Lourenzo, e a esperansa en Dios, que n’era prá menos. E non sin pena veu coma a viuda e Lourenzo foron ceando, antr'as bagoas, uns bocados de porco e de vaca que puñan med'os cristianos, e uns xarros de viño, que foran capaces de dar ánimos ó peito mas ${ }^{7}$ angustiado. Pró ó mesmo tempo nada se falaba d'o particulare, e Xan non podia adiviñare como s'axeitaria Lourenzo, prá ganar a aposta que via por sua.

O fin trataron de s'ir deitar, e á Xan puxéronsell'os cabelos dreitos, cando veu qu'en tod'á casa n'habia mais qu'a cama d'o matrimonio, e qu'a viuda tanto petelexou prá que Lourenzo se deitase n'ela, qu'aquel tivo qu'obedecer, ind'ela, envolta n'un mantelo, á meterse detrás d'un taboado que no sobrado habia. 
Xan, c'a yalma nun fio, viu desd'ó fayado, donde lle votaron un-has pallas, coma viuda matou o cantil e todo quedou as escuras.

-Seica quedarás comigo, miña muliña branca, y abofé que te vin perdida, escramou estonces; ó fin as mulleres foron feitas d'un-ha nosa costilla e algo han de ter de bó. Sálvame, viudiña, sálvame d'este apreto, qu’inda serey capas de me casar contigo.

Deste modo falaba Xan prá si, anqu'ó mesmo tempo non podia cerrar ollo, qu'á cada paso lle parecia que runxian as pallas.

Asi pasou un-ha hora longa, en que Xan, contento, xa iba dormir descoidado, cando de pronto oyeu, pirmeiro un sospiro e despois outro, cal s'aqueles sospiros fosen d'alma d'outro mundo; estremeceuse Xan, e ergueuse prâ escoitar mellore.

¡¡Ay! ¡meu tio, meu tio! dixo entonces á viudiña; ¡que fria estou n’este taboado, pró mais frio estás ti, meu tio, nesa terriña que te vay comere!

-¡Ay! ¡meu tio, meu tio! escramou Lourenzo da outra banda, como si falase consigo mesmo; cánto m'acordo de ti, qu'eu estou no quente, e ti no CampoSanto, n'un leito de terra donde xa non tês compañia.

¡¡Ay! ¡Antonciño! Volveu á decir á viuda, ¡qué será de ti n’aquel burato, meu quiridiño, cando eu qu'estou baixo cuberto, bu! bu! bu!... ¡qué frio vay! ¡tembro coma si tuvese a perlesia! bu! bu! bu!...

¡Miña tia!

$-\succsim$ E seica non dormes, meu sobriño?

-E seica vos tampouco, ñ’a tia, que vos sento tembrare com'un-ha vara verde. 
- ¿Cómo quês ti que durma, acordándome nesta noite de xiada d'o teu tio, qu'ora dorme no Campo-Santo, frio com'a neve, cando s'él vivira durmiriamos ambos quentińos n'ese leito donde tí estás?

${ }_{-}$E non podiades vós poñervos aqui nun ladiño, anque fora envolta no mantelo coma estades, qu'antre tia e sobriño e o mesmo qu'antre nay e fillo, e ainda mais habendo necesidade coma agora, xa que non querés qu'eu yaya c'o dôr e c'o frio, y ê pecado, ñ'a tia, tentar contr'a saude?

-Deixa, meu fillo, deixa, qu'anque penso que mal n'oubera en qu'eu me deitase ó lado d'un sobriño coma ti, envolta no mantelo e por riba da roupa, estando coma estou tembrando, bu! bu! bu!... querom'ir afacendo, que moitas d'estas noites han de vir prá min no mondo, que s’antes fun rica e casada, agora son viuda e probe; e cando tiven meu, agora teu ê, qu'á min non me queda mais qu’o ceo y a terra.

-E... pois, miña tia... Aqui pr'entre dous pecadores, e sin que naide nos oya mais que, Dios, vouvos á decire, qu'eu sey d'un home rico e d'a sangre d'o voso difuntiño, que si vós quixérades, tomariavos por muller.

-Cala, sobriño, e no me fales d'outro home... qu'inda parés qu'o que tiven está vivo.

-Deixá, miña tía, qu’asi non perderedes nin casa, nin leito, nin facenda, qu’é moito perder d'un-ha ves; sin contar c'o meu tio, á quen ll'ei de decir tantas misas coma dias ten o ano prá que descanse e non vos veña á chamar nas noites d'inverno. Asi él estará aló ben, e vos aqui; s'el vivira, non outra cousa vos aconsellara, si non que tomárades outra ves home d'a sua sangre, xa qu'a xente d'a sua sangre lle deixou o qu'él e vós coméchedes xuntos n’a sua vida.

-E seica tês rason, meu sobriño, pró..., ¿`s'este era o teu pensamento, Anton, meu tio!, por qué no-me dixech'antes de morrer, qu'estonces eu o fixera anque for a contra voluntade, solo por te servire? 
-Po-la mińa conta, ñ'a tia, que si meu tio nada vos dixo, foy porque se ll'esqueceu c'o conto d'as agonias, e non vos estrañe qu'á calquera lle pasara outro tanto.

-Tês rason, tês, a mort'e moy negra, e n’aquela hora s'esquence. ¡Ay! ¡meu tio, meu tio! ¿qué non fixera eu por che dar gusto? ¡bu, bu, bu! ¡qué frio vay!

-Vinde pr'aqui, que si non vos asañás, díreivos qu'eu son o que vos quer por muller.

- ¿Tí que me dis, home? pró á ver qu’o adiviñei $\log ^{8}{ }^{8}$, que solo un sobriño d'o meu tio lle quixera cumprir asi á voluntade...

-Pró á ser, tiña que ser d'aqui á un mes, que despois teño qu'ir á Cais, en busca d'outra harencia, e quixera qu'antes quedárades outra ves dona d'o que foy voso. $\mathrm{O}$ qu'ha de ser, sea logo, qu'o fin meu tio hayo d'estar deseando desd'a tomba.

-¡Ay! ¡meu tio, meu tio! Qué sobriño che dou Dios, que mesmo d'oilo paréceme que t'estou oindo; Pro... meu fillo... ê ainda moy cedo, e anque tí e mais eu nos volveramos a casar c'o a entención de lle facer honra e recordar o difunto, o mundo murmura... e...

-Deixavos d'o mundo, que casaremos en secreto e nadie o saberá.

-E pois ben, meu sobriño, e solo pró9 qu'és da sangre d’o meu tio, e xa que me dis qu'10 s'ha d'alegrar n'a tomba de vernos xuntos... c'o demais... ¡ay! Dios me valla... ¡eu querialle moito á meu tio! ¡bu, bu, bu!... ¡cómo xia!

-Vinde pr'onda min envolta no mantelo, que n'ê pecado, xa qu'habés de ser miña muller.

-Pró ainda n’a son, meniño, e teño remorsos... ¡bu, bu, bu! qué frato me dá po-la cabeza e po-lo corason. 
-Ñ'a tia, vinde, e deixavos d'atentar contr'á saude, que s'algo pecásedes antes de casar, témonos que confesare.

-Irey, logo... irey, que necesito un pouco de caloriño.

Estonces sintironse pasadas, ruxiron as pallas, e a viuda escramou con moita dolore.

-¡Ay! ¡miña virxe do Carme, qu’axiña t’ofendo!

-¡Ay! ¡miña muliña branca, qu’axiña te perdo ${ }^{11}$ !

Marmurou estonces Xan, con sentimento e con coraxe. E chegándose en seguid'á porta do sobrado, berrou con forza:

¡Meu amo, a casa arde!

-Non arde, home, non, qu'ê rescoldo.

-Pois rescoldo ou lua, s'agora non vindes voume c'a mula ${ }^{12}$.

E Lourenzo, saltando d'un golpe ó chan, dixo:

-Aguardá, logo. -¡Esperaime, ñ’a tia, que logo volvo ${ }^{13}$ !

E hay cen anos que foy esto, e ainda oxe espera á viudiña po-lo sobriño d'o seu tio. 


\section{Notas (por M. C. R. P.)}

1 Erro, quizais do editor, por «tusiras» pois é un pluscuamperfecto equivalente a «tusirías ou habías tusir». 2 Así no orixinal.

3 Nota do autor: N'algun-has aldeas de Galicia solen a (sic) mulleres chamar tios ôs maridos.

4 No texto debería ser "qu’o qu'é teu é meu, Margarida".

5 O correcto sería "por».

6 Expresión castelanizante que busca a rima con «casare».

7 Así no orixinal.

8 A frase non está moi clara. Evidentemente quere dicir «Pois mira por onde, xa o adiviñara», quizais lle falte algunha palabra.

9 Debería ser «por».

10 Así no orixinal.

11 Quizais o texto debera marcar os versos:

¡¡Ay! ¡miña, Virxe do Carme,

qu'axiña t'ofendo!

¡¡A! ¡miña muliña branca, qu'axiña te perdo!

12 Quizais tamén aquí se debería salientar a forma versificada:

Pois rescoldo ou lua,

se agora non vindes

voume c'a mula.

13 Tamén aquí debería salientar a parte rimada, colocando as frases en forma versificada:

-Aguardá, logo.

-¡Esperaime, ñ’a tía,

que logo volvo! 
CONTOS DA MIÑA TERRA

わが故郷の昔話 
日が暮れようとしている冬のある日、30 歳の厄年になる小学校 からの仲良しの 2 人は、ゆっくりとした足取りで歩いていた。一人 は、白毛の太った尻の丸いラバにまたがり、そしてもう一人は立った まま足を休ませていた。ラバの主は軽い手綱さばきをしているので、 ラバは怒っているようには見えなかった。

立っている男はラバに乗っている男と同じくらいの速さで走っ たので、額と毛先に汗が流れていた。ラバの上にいる男は、相棒の 汗を見ながら言った。

「ところで、ロウレンソ、この道で荷物を運ぶ家畜を買ったらど うだい。山や砂地を何キロも歩くこいつは犬とも仲良しさ。」

「家畜だって！いいけれども、家畜がお前たちを乗せて行くの か。大きな馬は歩いても歩かなくても、小さな馬より価值があると 思うけど、大きな馬を持っていても、馬がなくても自分の足でやっ ていけるさ。足は水も飲まないし、食べないし、何もいらないさ。」

「ほんとうに、お前の歩き方は何よりも一番安上がりだ。俺は辛 いよ! 家畜といっしょに行く時には使用料を払うだけさ。神様から授 かったこの足でお前のようにはできないよ。でも・・・こんなふうに して人間の足が疲れないように家畜の足で一中日歩くのは嫌じやない さ。それで、さっきも言ったけじ、お前は休憩するために馬を買うべ きだよ。だから、お前も他の人がするようにしな。つまり、俺は今日 稼いで、食べて、明日は分からない。お前は高価なものも馬具も持っ てないから、結局、ザル貝が好きなんだろう。つまり、ザル貝採りの 女たちはリベイロワインとカリール産の牡蠣が好きなように。ロウレ ンソよ、結婚しな! 仕舞には時は移り、年月は経ち、貧しい男は年老 いて、寝床で毛布にくるまって、時期を逃すと、そのまえに白髪にな ってしまうぞ。だから、ロウレンソ、働き手がいて、男が稼ぐお金を 仕舞い込む女が要るんだよ。」 
「好きにしたらいいさ。（気ままな牛はよく舐める、という彥。） \rfloor

「自惚れよ。それは噂話さ。男は女と最後には一緒にならなけれ ば、何のために生まれてきたのか。お前は母親から生まれたのに。（ ロウレンソは咳こみ）お前のことを悪く言うと、たぶん夜露に濡れて 風邪をひいたな。（ロウレンソは再び咳こみ）お前が、咳をせずに、 馬に乗って足を広げて来れば確実に俺を連れて行ってくれる。」

「俺、風邪ひいたかな。今までそんなことなかったし、思うに考 えても見なかった。しかしだな、結婚のことについて話されると俺は いつも咳がでて・・・ヘヘン！・・・ヘヘン！・・・たぶん、その前 ぶれだよ!シャン、お前、そう思はないか。」

「思うに、お前は隅っこのブドウみたいに引っ込みがちで、生ま れたばかりの赤ちゃんさ。カニのように横歩きするのをやめられな い。どうしてお前が女のひとの悪口を言うのか俺には分からない。 お前はとても愛されて、王子様のように信頼されてお祭りでも優しく される。そして、お前のお母さんが女だったとわかり、お母さんがい なかったら、お前は世の中の一人として生まれてこなかったのに。」

「たとえ生まれて来なくても、道を踏み外すことはない。生活の 糧を得るのに汗を流して働くのはいいことだよ。それから、お祭り でも、お祭りでもなくても不平を言って、女の子たちと一緒に男た ちを騙しながら、いい若者なのに手古摺らせると神様が褒めてくれ ない。」

「時々、思うんだけど、何も言われないと司祭に挨拶しないあい つらの一人と同じなら、畜生だ! ところで、お前は、言いたいこと なら何でも言えるやつさ。俺には守ってくれる人が欲しいんだ。そ れから、俺はお祭りの前には結婚するさ。神様はこうして俺に応え てくれるんだ。」 
「シャン、たとえ冬であっても、神様はお前がそんなに汗をかか ないようにしてくれるさ。結婚について俺に話してくれるときお前 は俺よりも咳をする。お前は、お祭りで羊を殺さないと思うが、戸 口で高らかに浮気話するのは結婚した者には罰当たりだ、他人に向 かって悪口を投げかけるのは疾うに悪いと分かっている。神様、俺 達を助けて ! 」

「ところでお前が、女たちの浮気話や悪さについて話すのは老婆 の昔話のように俺には思えるが、じうしてか知りたいかい。つまり、 俺たちの村では、犬が狂犬病にかかると、確かであろうとなからう と、グルッと回って犬は自殺する、と言われている。それで、俺はお 前に約束するけど、大人が俺に話してくれるように、熱心に祈らない と独り身の女も既婚の女も、決して見つからないよ。つまり、まだそ んなに悪い若者だと俺は思わないよ。たとえ、やつにそう言うことが 自惚れであってもさ。」

「それは結婚することかい。たぶん、シャン、お前は見つけられ るよ。つまり、他人に対して男が望むように必ず見つかるよ。（諺・ 莕置き場の後ろには犬はいない。）俺はお前に言うけど、世の中に は、お前たち男のために子供を産んでくれる女、いい女はたくさんい るさ。だから、シャン、悪魔のような女たちはやめな。女は悪魔さ。 人の言うことにや、どの聖人が賢いか俺は知らないさ。だから、悪魔 は神様のところまで遠くから角を立てるという。」

\section{「ちくしょう!」}

「お前はよく知られている名前を徳く呼ばれるようになるさ。お 前の妻になる人の家の屋根から、お前に影がさすというわけだから さ。」

「たぶん、あの別の女が俺を欲しがっている! まあなあ、ロウレ ンソ、お前の知らない人についてそんなふうに話すべきじやないよ。 女はみんな明るい目つきをしているわけじゃないけじ、何人もの命を 授けるものだと言うことを知っている。」 
「約束は言ったとおりになる。話すとわかるさ。つまり、お前に 繰り返して言うが、女なら、俺は誰でもいいというわけじやない。侯 爵婦人であろうと貴族の血筋でもあっても。よく言うことにや、お互 いに同じ肉と血で作られ、同じ足を引きずる。神様は俺の家庭を助け てくれる、時には隣の家庭に唾を吐くこともある。」

「ああ！他人の名誉を盗むやつ。もしお前が俺の名誉に唾を吐く のを望んでいるなら、お前を悪魔のところに連れていくぞ。お前のよ うに引っ込みがちのやつには、たぶん俺が妻を養うという考えは、俺 が真っ当な人間になって、お前を考え込ませてしまう。だけど・・・ はっきり言うと、ロウレンソ、俺たちはいい友達だ。お前は、俺より も賢い。よく考えると、お前の行くところどこでも感心するように何 事もうまく片づけた。一方、俺は、煮たった鍋に、コオロギが鳴いて 火元を見ているようだ。もし、話が、話がまとまっているなら・・・ 、大勢の女たちの中に俺を放り込んで、ひとりも女を与えず、俺に汗 を流させる聖人の価值はある。さあ！もう、いい女たちに会ったと言 え。女はみんな角を名誉ある男の頭に付けることはできやしない。」

「女はみんな、シャン、女はみんな。つまり、シャンたちには、 なにかもっと、名前が女を侮辱すると思われている。」

「俺のことを責めているのは、確かだと思うよ。だけど。俺の父 と母は結婚したし、俺も結婚したい。庭の入り口で腰掛けておもむ ろに話す夫婦を夜になって見かけたとき、おもわず目が行ってしま う。一方では、イチヂクの木の下で月明かりのもと子供たちが走っ ている。」

「やめな、やめな! 絵空事はやめな。ちよっと抓られたり引つ掻 かれたりして、さらに、だんだん軽荗されるよ。」

「本当のところ、俺、結婚は良くないと思う。どんなに俺が心 配しても愛情は俺を裏切る。しかし、結婚するとしたら、若いとき 
に、健康で分別があり働き者の女と結婚しようといつも思い、たぶん そのことはそんなに悪いことだと思わない・・・どう思う？」

「お前はラバのように頑固だから。シャン、お前には悪魔がい る。それとも、結婚にワクワクしているかい。だけど、神様が命じ たように後戻りできないのは分かっている。女たちのことをざっく ばらんに言うと、女はみんな籠のようで、足がない犬のように横た わっている。」

こんなふうにシャンとロウレンソは話しながら、とある村の近く にやって来た。やがて、遠くから叫び声と泣き声が聞こえはじめた。 すこし止んだ後で、そこを通りすぎると葬式だということがわかっ た。そして、やって来たひとりの男の子に 2 人は死者のことをたず 漦た。すると、まだうら若い女が未亡人になり、子供がいなかった 女の旦那の葬式で、旦那はその村の者じゃなくて、別に跡継ぎがい る、と返事をした。

少年は立ち去った。そして、ロウレンソはシャンのところに来る と、こんなことを言った。

「シャン、いい機会だから、女たちに会ったらどうだい?」

「え、なんだって?」

「そのやもめは、わが生涯で一度も会ったことのない人で、誰だ か俺は知らないが、いい機会だから今晚結婚の契りをひと月先にし たらいいだろう。」

「ところで、ロウレンソ、お前正気かい? 」

「シャン、お前よりも悋。望むのか望まないのか? 」

「うーん、ところで、お馬鹿さん。賭けよう。それで、もしお 前が勝てば、親父から貴って一年になる白いラバをあげるよ。それか ら少女のようにとても可愛いラバに愛情を感じるさ。そしたら結婚の 
悪夢から解放されるだろう。もしお前が負ければ、馬を買って、俺の 宝物の女の人の悪口を二度と言うなよ。まだ白いラバより女のほうが 好きなんだ。」

「支度しな、さあ、ラバから降りろよ、そして今から俺はお前に 嫌なことを言うから全部やれよ。そして明日の朝方までお前はシャン でもないし俺もロウレンソじゃなくて、お前は俺の召使で、俺はお前 の主だから。さあ、ラバのことを考えながら俺の後に続け。俺は前に 行こう。何にでも賛成しろよ。」

俺の言つたこと、俺のしたことは。

ロウレンソは先に出て、シャンはロバの手綱を引きながら歩きは じめた。それは他の動物と同じように可愛らしかった。そして急い だ。

彼らが墓地に着こうとしていたまさにその時に、教区の黒く穴の あいた旗が行く手を阻むように埋葬も始まろうとしていた。司祭を泣 かせようとしていた女たちはまるで他人事のように髪を引つ張りなが ら、ラバを連れていた人を歩かせないような方法で墓にしがみつき声 がかれるまで叫んでいた。

「ああ、アントン!アントン! わたしの友アントン、道で会う と、いつもあんたは私に言ってたわね。さようなら、マリキーニャ! って。さようなら、アントン。もう二度と会えないねえ。」と、一人 の女が頭の上に両手で十字を切ったマグダレナのような恰好をしなが ら言っていた。

もう一人の女は、枢にすがりながらこんなことも言っていた。

「どこにいるの、アントン。もう、わたしに話してくれないね。 アントン、可哀そうな人よ。あんたにはベージュのリンネルのカル ソン(七分のズボン)を私の手で作って穿かせてあげた、アントン。誰 
が、今、あんたに新しい上着をきせて、カルソンを穿かせてくれるの かしら、アントン。」

未亡人とその姪、みんな遠服を着て涙に溢れて、壊れかけた扇と ほつれたハンケチを持ってまだ叫んでいた。とくに、未亡人は墓の下 に時々入ろうとして、カずくで墓を引っ張り、言っていた。

「ああ、おまえさん。ああ、おまえさん。銀のように美しく、金 のように赤く、おまえさんのバターのような肉をなんで土が食べてし まうの。あんたは、逝ってしまう。あんたは逝ってしまう。今、私を 守ってくれるのは誰かしら。私の幸せをおまえさんが言ったように誰 が私に言ってくれるかしら。お食べ、マルガリィディーニヤ、たらふ くお食べ。おまえさんは、わたしの聖マルガリイディーニ中。おまえ さんが足を引きずれば、私も足を引きずって。さようなら、おまえさ ん、もう二度と一緒にベッドでは寝られない亦え。アントン、おまえ さんのもとに誰がわたしを連れていってくれるのかしら、最期までお まえさんと一緒に、私の宝物よ、私の気持ちを分かっておくれ。」

こんなふうに、未亡人は死者に向かって不幸を言い続けていた。 その時、突然、ロウレンソは女たちの中に分け入った。女たちは八ン ケチで目をおおい、魂から湧き出るかのような寸すり泣きをして、す すり泣きする女たちよりさらに叫びながら、叫んだ。

「ああ、叔父さん！ああ、叔父さん！墓の中にいるのがぼくは分 かっている。生きている叔父さんに会いに、ここに来られなかった。 叔父さんは跡取りのために遺言をのこしてくれた。いつも、叔父さ んを父のように好きだった。だから、叔父さんにお別れするために ぼくの名を呼んでくれよ。叔父さんはもう死んでいる。心の絆が離 れてしまう。ああ、叔父さん! ああ、叔父さん! ぼくは悲しみで死 にそうだ。」

す寸り泣きをしている女たちがこれを聞いた時、ロウレンソのま わりに立ちすくみ、思っていた悲しみでいっぱいになり爪先から崩 れた。 
「ところで、おまえは誰だい」と、彼にとても同情して女たちは 訊いた。

「ぼくはアンドゥルコです。このひとの甥っ子です。亡くなる前 にぼくに別れを告げるために手紙をよこして、ぼくを跡取りにする からと言ったんだ。だから、畑のなかをたくさん歩いて来たので、 墓の中で叔父さんに会えたよ。ああ、叔父さん。ああ、叔父さん!」

「ところで、小僧、お前はどこの生まれだい。」

「ぼくは、叔父さんの生まれた土地の出身です。」

ロウレンソは、そそり泣きながら再び言って、話を遮った。

「で、お前の叔父さんはどこの生まれだったかな。」

「ぼくの叔父さんは、ぼくの土地の生まれだよ。」

そして、このことを取り上げることなく、泣き続けていた。ロウ レンソは未亡人のほうに近づいていったが、まだ涙でいっぱいの彼女 に、叔父さんのことで泣いていたその燷々しい若者はのぞきこんだ。 一緒に顔を見合わせた後、ロウレンソは亡くなった人の跡取りだと彼 女に言った。そして彼女はとてもいい目つきの若者を見つめて、埋葬 が終わってから一緒に家に行こうと言った。まさにそこに夫の侽っ子 が立ち止って、不幸を一緒に泣いていた。

「悲しい、とっても悲しい。ああ、ぼくの叔父さん。みんなを慰 めて、心から彼のためにたくさんお祈りをするようにぼくは任され たんだ。彼が安らかに眠り、そして、この土地でぼくたちが最大の 慰めができるように、さらに、ぼくの叔母さんのために、神様はぼ くたちに仕事して落ち着くように命ぜられた。そして・・・叔母さ んは好むと好まざるにかかわらず、他人が言ったように、叔父さん はこの村で亡くなったから、それから・・・何したらいいのかな？ぼ 
くたちも生きて行かなきやならない。それがこの世さ」と、ロウレン ソは言った。

こんなふうに話しながら泣きながら、みんなは未亡人の家のほう に道を引き返した。そしてシャンはラバの後を歩いていた。最初のう ちはロウレンソがする目配せに気がつかず、のぞき込みはじめた。す るとある種の寒気が体をはしり、自分のことを考えながら自分の白い ラバがいなくなりそうだと思っていた。しかし、未亡人の悲しみと涙 を見ると、彼は冷淡な顔で一直線に走り去れず、再び神様と彼に救い を求めている女たちを信頼するようになった。

「ところで、叔母さん、ぼくのこのラバと使用人が寝る場所があ るかい。ぼくたちキツネのようにながいこと歩いてきて疲れている から。」

「みんなあるさ、おまえは私の夫の甥っ子だもの。私はおまえに 会えて、今、おまえを見て、私をとっても慰めてくれるように思え る。」

「ありったけの慰めを未亡人にしてあげなよ」。ラバを家畜小屋 に入れながらシャンはつぶやいた。「このことのために結婚しな、 愛すべき人だよ。」と、満足げに付け加えた。

そして、こうした望みとともに、ランプの火が灯りまつ毛を紅く 染めて、リベイロワインの入ったクンカ(杯)をいっぱいにしながら未 亡人がさし出した豚肉のひと切れを喜んで食べ始めた。一方、叔母さ んと甥っ子は一緒に来た人たちと後継ぎと死者のことを話しながら上 の屋根裏部屋にいた。

$$
\text { そうこうしているうちに夜になった。ロウレンソとシャンの } 2
$$
人は未亡人の家に泊まった。扉が閉まったのを見はからってから、白 いラバとロウレンソは少なくとも神様の恵みを待ちわびていた。そし て、涙であふれキリス卜教徒には怖い話だが、豚肉と牛肉を二切れ、 それに苦しい心のうちを勇気づけるためにたっぷりワインの入った䝂 
を置いて、なにごともなかったかのように未亡人とロウレンソが夕食 をとっているのが見えた。その刻にとりとめのない話をしていたシャ ンは、賭金を稼ぐためにロウレンソがどうして自分のために工面した か当てることができなかった。

結局、寝ることにして、シャンは家じゅう探しても夫婦のベッ ドしかないのがわかると髪が逆立った。そして、未亡人はロウレンソ が横になれるような場所に促した。彼女はもう屋根裏部屋の梁の後ろ で隠れるように毛布にくるまっていた。

魂に糸を通すほどの神経質なシャンは、未亡人がランプの灯り を消し真っ暗にして葍のなかにくるまっているのが見えた。

「俺の白いラバよ、たぶんおまえは俺と一緒だ。で、もしかする とおまえと別れることになる。結局、女たちは俺たちのあばら骨から からできていて、素晴らしいものを持つようになったのさ。後生だか ら、後家さん、あんたと結婚する器量は俺にはなさそうだから、この 契りを反故にしてくれ。」と、その時叫んだ。

まさにそのころ、目を閉じることもできずこんなふうにシャンは 独りごとを言っていたが、そのたびに菜がガサガサ吟っていた。

こうして長い時間がたち、満足したシャンは気に留めず眠りに 入ってしまった。その時、突然、溜息、そしてそのあとにまた溜息が 聞こえた。あの溜息はあの世のものからのようだった。シャンは身ぶ るいして起き上った。そしてもっとよく聴いた。

「ああ、あんた、あんた。この床板の上であたしはとっても寒 いよ。あんたは、あんたを喰ってしまう土のなかでもっと寒いだろ うよ。」と、その時、未亡人は言った。

「ああ、叔父さん、叔父さん。ぼくはおじさんのことを思い出し て熱くなりそうだ。墓場にいる叔父さん、もう一緒に寝てくれない、 地中の寝室にいる叔父さん。」と、ロウレンソは向こう側で叫んだ。 
「ああ、アントンシーニョ。愛するあんたは、あの穴のなかで どうなるのかしら。そして、あたしはうずくまって、ブル、ブル、ブ ル。なんて寒いのかしら。麻痺したかのように震えて。ブル、ブル、 ブル。」と、未亡人は再び言った。

「叔母さん。」

「私の甥っ子や、たぶん眠れないのかい。」

「叔母さんも、きっと眠れないの、細い枝のように震えている のがわかるよ。」

「今晚のように凍てつく夜は、お前は叔父さんさんのことを思い 出しながら眠ってほしいと望んでいるけど、叔父さんは雪のように寒 い墓場で眠っている。もし彼が生きていたら、おまえがいる寝床であ たしたちは一緒に温かく眠っているのになあ。」

「だからこの隣で叔母さんと寝ることはできないよ。叔母さんは 今いる処で毛布にくるまっているけど、ぼくが床で眠るのを叔母さん は望んでないから、叔母さんは悲しみと寒さでいっぱいになった。だ から、叔母さん、健康に害することは罪つくりだ。」

「放っといて、お前、放っといて。甥っ子のそばで服の上から 毛布にくるまり、あたしがブル、ブル、ブル・・・震えて静かに 寝るのは体に悪いと思うけじ、あたしはすぐ慣れるさ。この世で、 毎晚、あたしは生きていくさ。もし、以前、豊かに暮らし結婚してい ても、いまは未亡人で貧しいからね。今のあたしにあるものはおまえ だ。あたしには天と地しかないさ。」

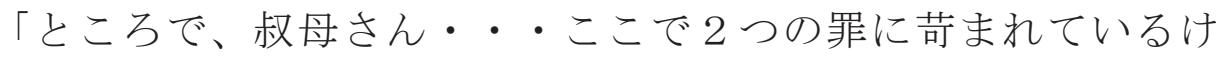
ど、ぼくたちの話を神様だけが聞いてくれるなら、ぼくは叔母さん に言うつもりだよ。ぼくは金持ちで亡くなった人の血筋にあたる人だ から、もし望むならあんたを奥さんと思ってもいいよ。」 
「お黙り、甥っ子や。他の男のことについて私に話すなんて・・ ・、私が一緒に暮らした人が死んだばかりなのに、おまえは何を思 っているのかい。」

「放っといて、叔母さん、叔母さんは家も寝床も畑もなくならな いさ。叔父さんと話もせずにいると、一度にたくさん失うことになる よ。つまり、ぼくが毎日のようにミサをあげなければならない人に、 冬の夜に休息して名前を呼ばれないようにするためにも・・・。こう して、叔父さんはあの世で元気にしているだろうし、叔母さんはここ にいるし。で、叔父さんが生きていたら、ほかのことは叔母さんに忠 告しないよ。もし叔母さんが再び血縁の男を入れたら、叔父さんと叔 母さんは一緒に生活したことをその男に話しておくかい。」

「で、侽っ子や、おまえの言うことが道理だ。でも、もし、これ がおまえの考えなら、アントン、おまえさん、死ぬ前にどうして私に そのことを言ってくれなかったのかい。意志に逆らってでも、あんた にだけ仕えたいので、あたしはやり遂げたよ。」

「叔母さん、ぼくの話はね、ぼくの叔父さんが叔母さんに何も言 わなかったのは、叔父さんが断末魔の話を忘れたからだった。叔母 さんには不思議とは思わないけど、誰でも同じようなことがまた起 こるだろう。」

「おまえが正しいよ、甥っ子のおまえが。死は不吉だし、あの 時はみんな忘れている。ああ、あんた、あんた。あたしはあんたの 気に入ることをしなかったんだろうか。ブル、ブル、ブル・・・、 何て寒いんだろう。」

「こっちへ、おいでよ。もし叔父さんを怒らせないなら、叔母さ んが女として叔父さんに望むことはぼくだと思うよ。」

「あんたは何てこと言うの。だから、すぐ察知したのよ。つま り、わたしの夫の甥っ子は、そんなふうに望みを果たそうとするだ けなのさ・・・」 
「そうだろう。ひと月はここに居なければならないし、そのあ と、別の遺産を探してカイスに行かなければならないし、それで、 その前に叔母さんはもう一度ぼくに残っていてほしと思うなら、あと で、叔父さんは、結局、墓場からそれを望んでいるだろう。」

「あ女、おまえさん、おまえさん。神様が与えてくれた侽っ子は なんとい寸ばらしいんだろう。同じようにそれを聞いて、あんたの 言うことをあたしは聞いているようだわ・・・。だが、甥っ子や、 まだ時期が早いしおまえとあたしで名誉のため死者を思い起こすつ もりで、もう一回結婚するけども、世間は陰口を言うし、・・・そ れから・・・」

「世間のことは放っといて、内緒で結婚しよう、そうすればだれ にも知られないだろう。」

「さて、ところで、甥っ子や、お前だけがわたしの夫の血縁者だ から、おまえがあたしに言うように、墓前に一緒に臨めば・・・他 人は・・・亦、何ということかしら・・・市たしは夫がとても好 きだったの。ブル、ブル、ブー・・・なんて凍りつくほど寒いのか しら。」

「毛布にくるまってぼくの方においでよ。ぼくの妻になるんだか ら罪なんかないさ。」

「でも、まだ、おまえ、あたしは怖いのよ・・・ブル、ブル、ブ ル。頭で考えても心で考えてもうんざりだわ。」

「叔母さん、おいでよ。健康に害することは気をつけて。もし罪 つくりなら、結婚する前に懺悔すればいいんだよ。」

「行くわ、今・・・、行くわよ。ちょっと暖がいるのよ。」 
その時、 2 人はただならぬ気配を感じた。葈が唸り、未亡人は悲 痛の叫びをあげた。

「ああ、わが聖カルメさま、わたしはあなたをすぐに怒らせてし まいます。」

「ああ、ぼくの白いラバは、すぐにいなくなるよ。」

その時、シャンは心持ち怒り、ぶつぶつ不平を言った。

そして屋根裏の屝に着くとすぐ、カいっぱい叫んだ。

「ご主人様、家が燃えるよ。」

「燃えないさ、違うよ。残り火さ。」

「う〜ん、火なのか、月あかりなのか。もしいまお前たちが来な ければ、ぼくはラバと出ていくぞ。」

それからロウレンソは、床を吒いて立ち上がり、言った。

「待ってて、すぐだから。叔母さん、ぼくを待っていておくれ。 すぐ戻るから。」

そうこうして 100 年がたった。今日も未亡人は、夫の甥っ子を 待ち続けている。 


\section{BibLIOGRAFÍA}

Rosalía Castro de Murguía, Conto gallego, Facsímile do documento custodiado na Real Academia Galega coa sinatura: MO-04/01.2, da autoría de Rosalía Castro e moi posiblemente autógrafo. Universidade da Coruña, 17 de maio de 2007.

Rosalía Castro, Contos do pobo, Edicións Castrelos, Vigo, 1970.

Angueira, Anxo. 2011: «O conto de Rosalía», A Trabe de Ouro 87, 417-428.

Noia Campos, C. 2010: Catálogo tipolóxico do conto galego de tradición oral. Servizo de Publicacións da Universidade de Vigo.

Ríos Panisse, M. C. 1995: «Contos da miña terra (1864), primeira edición do Conto gallego atribuído a Rosalía de Castro", Grial 126, 257-280.

Ríos Panisse, M. C. 1999: «A orixe popular de Contos da miña terra (Conto gallego), obra atribuída a Rosalía de Castro", Homenaxe ó profesor Camilo Flores, Universidade de Santiago de Compostela, 606-625.

Torres Regueiro, X. 2012: «O Conto galego de Rosalía, Unha edición ferrolá asinada pola autora en 1868», Grial 195, 118-123.

\section{おおりに}

Contos da miña terra『わが故郷の昔話』は、スペインガリシア地方の詩人Rosalía de Castroロサリーア・デ・カストロ (1837-1885)が、ガリシア語で書いたとされる物語です。

ロサリーアは、ガリシアの文芸復興と称されるレシュルディメント期において代表作Cantares gallegos 『ガリシアのうた』(1863)を著し、ガリシア人なら誰でも知っている閏 秀詩人です。

この昔話は、1864年にコルーニャ市で発行されたE1Avisadorという雑誌に掲載されました が、作者はR.C.とだけ記されていたために、いろいろと憶測されてきました。イニシャル から数人の作者が浮かびました。

サンティアゴ・デ・コンポステーラ大学のリオス・パニセ先生は、イニシャルのR. C. が果 たしてRosalía de Castroなのかどうか、さまざまな観点から詳細な調査を踏まえ、1995年 にその結果を発表し、作者はロサリーア・デ・カストロと断定しました。

物語のはじめにI. と記されていますが、おそらく作者は続篇を考えて敢えて記したのかもし れません。この話は、Noia Campos(2010)の分析から、アルネ・トンプソン1510のタイプ の昔話に分類されました。ロサリーアのこの物語と『ガリシアのうた』（拙編訳DTP出版， 2002)の「祝福された聖アントン」は話の筋が似ています。Edicións Castrelos版では0s dous amigos e a viuda(仲良しの 2 人と未亡人)という副題が付けられています。

こうして、ガリシアの文芸復興において詩に加えてロ承文芸という新たな分野においてもロ サリーアの重要性を映し出すことができました。

ガリシアには、語り継がれたおおくの昔話があり、言語研究のために重要な一次資料となっ ています。 
本書に転記した『わが故郷の昔話』はFolletín do Avisador, Contos da miña terra, por R. C. , Coruña Tipografía Galaica, Acevedo, 21, A. 1864 による。

巻頭言はロサリーア記念館長Anxo Angueiraアンショ・アンゲイラ先生、ならびにサンティ アゴ・デ・コンポステーラ大学Ríos Panisseリオス・パニセ先生にプロローグをいただ きました。朗読に当たってはInstituto da Lingua Galega研究員A. G. (Taboada Vilela, Lugo）さんの協力を得て、難解な作品の吹き込みをすることができました。上梓にあたり D T P出版の鳥居有一氏にお世話になりました。みなさまに、ここにお礼申し上げたい。 於東京プラド大師西 2014 


\title{
O CABO
}

Dende que empecei a estudar galego, interesáronme as obras de Rosalía de Castro.

No ano 2002 editouse a primeira edición de Cantares gallegos (en xaponés, Garisia no Uta) en Toquio, Xapón. Este libro ten 29 poemas traducidos ao xaponés. E logo, no ano 2009, aumentei eu e corrixín a tradución de Cantares gallegos $+\mathrm{CD}$, e son xa 31 os poemas traducidos.

Con esta tradución tendín unha ponte literaria entre Galicia e Xapón. Coido que os meus paisanos poden entende-la alma de Rosalía polo menos, é dicir, a lingua e a cultura galegas a través da miña tradución.

Agora, de novo, fixen unha tradución de "Contos da miña terra» da mesma autora. Esta narrativa foi edidada na Revista El Avisador en 1864. Despois de 150 anos, vai saír á luz esta obriña que traducín eu ao xaponés. Seguro que é a primeira vez coma a lingua estranxeira.

O único conto en prosa de Rosalía de Castro, non recollido en libro ata agora. A cantora mostra a veta do seu humorismo feiticeiro.

O traducir este conto por R. C. ó xaponés non me foi doado. Porque o galego e o xaponés son as dúas linguas absolutamente distintas. Entre dúas linguas non hai relación de parentesco lingüístico. Por iso comencei facendo unha tradución literal ó xaponés, pero intentei tamén transmitir da mellor maneira que puiden por medio da miña lingua, o xaponés, o sentido de cada frase. Penso que necesita unha lectura contextualizada, é dicir, histórico-cultural, estrutural e sintagmática, para entendermos correctamente. Entendo así traducín "Contos da mińa terra» ao xaponés.

\author{
Takekazu Asaka \\ Embaixador da lingua galega no Xapón \\ take_xapones@yahoo.co.jp
}

